\title{
Strategic Leadership, Good Governance: Analysis and The effect to Performance
}

\author{
Ria Mardiana Yusuf ${ }^{1}$, M. Guntur Hamzah ${ }^{2}$, Shinta D. Tikson ${ }^{3}$ \\ ${ }^{1}$ Economic and Business Faculty of Hasanuddin University, Makassar, Indonesia \\ ${ }^{2}$ Law Faculty of Hasanuddin University, Makassar, Indonesia \\ ${ }^{3}$ Economic and Business Faculty of Hasanuddin University, Makassar, Indonesia \\ riamard@unhas.ac.id,guntur9@gmail.com, shintatikson@gmail.com
}

\begin{abstract}
The aim of the paper is to propose a good governance framework based upon strategic leadership style to the government performance. The sampling method is done using a Krejcie and Morgan table that will determine the number of the sample based on population size in the four work units of government SKPD. Therefore a number of samples representative of the population of 110 government employees is 86 government employees divided into the four SKPD departments. Using a sample of four work units animal husbandries and healthy animals, fisheries, plantations, agriculture and horticulture officials in the Eastern Indonesian provincial government and a cross-sectional survey design, the result shows that there is a significant direct effect relating strategic leadership to the performance of the government and to the good governance. However, there is no significant direct effect on good governance to the performance of government.
\end{abstract}

Keywords: strategic leadership, good governance, government performance.

\section{Introduction}

The phenomenal Weber's theory about bureaucratic rationalization had been a management milestone in public institutions. He pointed out that rationalization is the way out for public institutions to be more efficient [1]. Known as "bureaucratic theory", Weber emphasized on specialization and division of labor, professionalism, and rules of law through organizational structure, procedures, responsibilities, and job hierarchy to be the most important aspect of the public institutions.

The management of public institutions - based on Weber's theory of traditional public administration and bureaucracy - recently considered inefficient, unresponsive and unproductive therefore consequently it has shifted towards a new era of public management or known as new public management (NPM). NPM emphasized [2] on flexibility, performance, money increasing value and cost-effectiveness.

According to the Government Law No. 32 2004, the changes trigger a shift in the governance bureaucratic management system from centralized to decentralize which cause authority governance decentralization that formerly is obligatory to the functions of central government but now involving regency and city government. This means local governments have the flexibility, more precisely the autonomy to organize their own administration. The main consequence of local autonomy in the form of authority decentralization of central government to local government is the creation of the communitydriven development paradigm [3]. It is up to the government to create and provide community involvement and reinforcement in the public service policy planning and decision-making. One of the basic concepts of "Good Governance" is the system involvement and community participation which was first resonated by UNDP, World Bank, and $\mathrm{ADB}$ as a discourse to recognize the public administration system in Indonesia.

One clear manifestation of good governance is the performance of governance principles application that serves as services of activities. However, without the "good governance" supporting the leadership style, the achievement of optimal performance by public institutions is merely rhetorical. The concept of "good governance" realized leadership as an ideal of clear vision, democratic, responsive, and responsible leadership [4]. Therefore, this type of typical leadership described by Thoha is known as strategic leadership.

According to previous studies, strategic leadership style is the one to be believed able to reduce problems in public institutions. Based on the findings by the Center for Population and Policy Studies UGM proves that Indonesia's public service practices in regencies/cities are still concerned with uncertainty of cost, time and service method [5]. These findings also reflected the practice of good governance in South Sulawesi. Therefore, it is highly attractive as a research topic because this 
study is the development of previous research. This study tries to assess the application of "good governance" system in relation to the leadership style in terms of employees' perception of the government system.

\section{Literature Review 2.1 Strategic Leadership}

One of the variables that will be analyzed in this study is the leadership style, based on the rapid evolution of development theory. It started from the paradigm used in studying the leadership theory based on the micro and macro perspective of the organization, and in a stable environmental conditions in the midst of uncertainty (chaos).

Charismatic leadership is a leader who has a vision, energy, and ability to influence people. Nowadays, development of leadership theory leads to strategic leadership. This theory argues that leadership behavior is not the main factor that could contribute to effective outcomes, but determined by the situation in which the leader is able to integrate the appropriate leadership style to his or her followers. That is the process which the leader and follower cooperate (engage) reciprocally to achieve the common goal [6].

According to Nicholson [7], in the key contribution of a leader can be defined as three main elements. First, accepting the leader role. By accepting the role, a leader can help create a powerful commitment to ensure quality and service delivery. Second is values. A leader infiltrates integrity, responsiveness, and standards into leadership. Third, determine leadership model. Nicholson continues by suggesting that leadership model depends on what best suited for the organization, and a person who has the skills of communicating, team building, giving feedback, delegating, coaching, and influencing. These elements can be implemented in private and public organizations.

\subsection{Government's Role in Public Service and Good Governance}

United Nations Development Programme (UNDP) identified the characteristics of good system of governance, i.e. 1) participation, where every citizen has a voice in decision-making, either directly or through intermediation of legitimization institutions representing their interests; 2) transparency, the information free-flow and can be received directly to the people in need; 3) openness, the opened-opportunity comments and criticism by the people to the untransparent-judge government; and 4) rule of law, the rule of law and a sense of justice guaranteed by any public policy is made and implemented [8].

\section{Conceptual Framework}

The construct variable between strategic leadership, good governance, and performance of public institution could be described below.

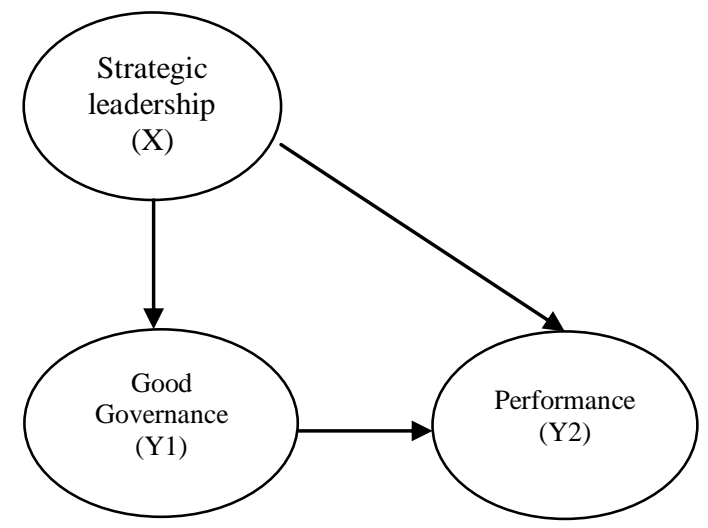

Figure 1. Diagram line of Strategic Leadership, Good Governance, and Performance.

Based on Figure 1. The following hypotheses as follows: 1) Strategic leadership has a significant direct effect on the performance of government and to the good governance, 2) good governance has a significant direct effect on the performance.

\section{Research Methodology}

The study used the survey method, the research took samples from a population and used questionnaires as the data collection instrument. In term of the time dimension, this study used crosssectional design. The unit analysis is the structural employees and head of fields in Department of Animal Husbandry and Animal Health, Department of Marine and Fisheries, Department of Forestry and Department of Agriculture and Horticulture which all located in Makassar. The reason these four Departments of Regional Work Unit (SKPD) are chosen as samples representing South Sulawesi Government is that they have similar characteristics in the job description, and had become the pillars of the main strategic competencies for the economic improvements in South Sulawesi. Based on the Government Law No. 32 2004, SKPD is the executive function implementer of local government, both provincial and regency/city should coordinate with one 
another in order to implement local government functions.

The sampling method is done using a Krejcie and Morgan table. Based on data of the head field, secretarial field and four subsections of the secretarial field in the Departments, all of which is about 110 employees. Based on the Krejcie and Morgan table, with a 95\% confidence level, a number of samples representative of the population is 86 employees and from All 86 samples are divided evenly into four SKPD Departments, which means the departments will be represented approximately by 22 respondents [1]. By using questionnaires and in-depth observation as data collection devices for the exogenous variables of strategic leadership (X1), good governance (Y1) and government performance (Y2) as an endogenous variable. The study uses a path analysis and the smart PLS software as analytical constructs test.

\section{Results and Discussion}

\subsection{Result}

The result of path analysis on the standardized coefficient from PLS is given in Figure 2 and Table 1 below.

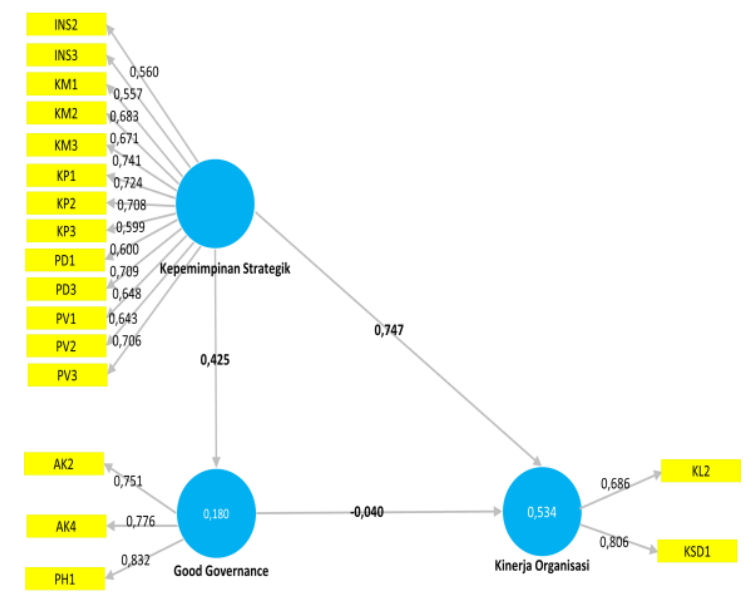

Figure 2. Results of path analysis influence of leadership on good governance on organizational performance.
Table 1. Statistics Test Results on Direct and Indirect Influence of The Government Performance.

\begin{tabular}{|l|c|c|}
\hline $\begin{array}{c}\text { The effect of } \\
\text { variable }\end{array}$ & Direct & $\begin{array}{c}\text { Indirect through } \\
\text { Good Governance } \\
\text { (GG/G2) }\end{array}$ \\
\hline GG $\rightarrow$ P & -0.040 & \\
\hline SL $\rightarrow$ GG & 0.425 & \\
\hline SL $\rightarrow$ P & 0.747 & $0.425 \times-0,040=-0.017$ \\
\hline
\end{tabular}

Source: processed data

Table 1 illustrates the test results of direct and indirect relationships of strategic leadership on government organizational performance through good governance. The table shows that the line variables coefficient indicates that there is a negative and unsignificant influence between good governance with government performance. However, there is a direct effect between strategic leadership to the government performance and good governance with the line coefficient scores 0.747 and 0.425. According to the hypothesis test, Table 1 describing that first hypothesis was true that strategic leadership has a significant effect on the performance and good governance in a positive value. For the second hypotheses, good governance has unsignificant effect to the performance in a negative value. Therefore the second hypotheses were failed or rejected by the testing.

\subsection{Discussion}

Literature and the results of studies have found the importance of leadership to keep the organization existence through motivating subordinates in achieving organization's vision. The leader, as a motivator, must match the personal interests of employees with the organization interests through the articulation manner that are acceptable to employees. The leader, also, could direct the organization towards good governance and optimal practices implementation [9]. It is stated that leaders, nowadays, face many problems of environmental change since business environment change very rapidly which impacted on the various internal decisions of organizations, whether it is private or government organizations [10].

One leadership style appropriate in the $21^{\text {st }}$ century is the strategic leadership that was characterized as someone who has the ability to empower subordinates and make changes as needed to anticipate environmental changes and maintains flexibility. in his article, characterized strategic 
leadership as a visionary leader who is responsive to change, responsible, professional, and competent. Competency and ability possessed by strategic leader include having good motivation and communication skills in directing the organization to achieve its goals [11]. Furthermore, the concept more specifically and described strategic leadership as visionary [11], has good communication skills, able to influence subordinates informally, motivator, strategic thinking, managing changes, managing conflicts, increase self-confidence, empower subordinates and the ability to be flexible but still have principles. This study adopted Thoaha and Burns concepts by defining variables of study based on the options and perceptions of public organizations employees to visionary leadership, sincerity in leadership, self-confidence, competency, and inspiration of the subordinates. In general, respondents considered strategic leadership has been implemented at SKPD and departments located in South Sulawesi Government are competent. Based on the employees' assessment of the leadership of their leaders, they assume that their leaders are an excellent communicator. Most of them are able to deliver a wide range of vision, mission and accomplishing strategy to improve performance in public organizations.

This study using five indicators of good governance, they are accountability, the rule of law, openness, participation, and professionalism. Based on employees perception and assessment in the South Sulawesi Government. According to the respondents' answers, out of the five indicators, only two are valid - accountability and rule of law Between the two indicators, rule of law is the most dominant indicator in building good governance practice. This means that based on the employees' perception and assessment, good governance is highly dependent on the rule of law and the accountability of governance. This indicates that South Sulawesi provincial government has not performed as expected by some experts in the field. Therefore, it does not significantly affect the organization performance. Principally, governance is a political product that is used with the intent of securing the interest and safeguarding the society. For that reason, in order for the optimization of organization performance, it requires other indicators of good governance in strengthening the holistic and ideal organization governance. The findings reassert Max Weber theory that the spirit of the bureaucratic governance rationalization is like the iron cage of "imprisoning employees" [8]. It means that during this time, the governance applied by South Sulawesi Government refers to the rules imposed by the central government. The compliance shown by the leaders is basically very good, but the compliance rigidity would reduce innovation that is needed in the modern bureaucracy era.

\section{Summary}

1. Strategic leadership is directly and significantly affect the performance and good governance of South Sulawesi Government.

2. Good Governance is directly and unsignificantly affect the performance of South Sulawesi Government.

\section{Bibliography}

[1] Gajduschek, Gyorgy, 2003, Bureaucracy: Is it efficient? Is it not? Is that the question? Uncertainty reduction: an ignored element of bureaucratic rationality, Administration \& Society, Vol. 34 No. 6, January, pp. 700-723.

[2] Moore, Chris, 1996, Human Resource Management in the Public Sector, The Hand Book of Human Resource Management, Second Edition, Blackwell Publishers, Ltd, UK.

[3] Witoelar, Erna, 2001, Urgency Role and Public Participation Increasing in the Government Implementation at the Regional Autonomy Era Toward Creation of Local Good Governance, Presented at the workshop day boarding school Role In Community Empowerment and Participation of regional autonomy, $15^{\text {th }}$ July 2001, East Java.

[4] Thoaha, Miftah, 1997, Fostering Organizations (Diagnosis and Intervention Process), PT. Rajagrafindo Persada, Jakarta.

[5] Susiloadi, Priyanto, 2006, Role of Government and Public Participation In Public Service, Spirit Publik, Vol.2, No.2, hal.81-90.

[6] Rosenbach, W., 2003, The Essence of Leadership, New Zealand Management, 50(3), 18-20.

[7] Rothwell, W.J. et al. 2008. Human Resource Transformation: demonstrating strategic leadership in the face of future trends. DaviesBlack Publishing, California.

[8] Widodo, Joko, 2001, Good Governance, Accountability and Bureaucratic Control, Insan Cendekia Publisher, Surabaya.

[9] Boonleaing, Sombut, 2014, The Good Governance Levels of Leaders of Local Administrative Organizations in the 
Phetchabun Province, Asian Social Science, Vol. 10. No. 18.

[10] Shamir, B., House, R.J., and Arthur M.B., 1993, The motivational effects of charismatic leadership: A self-concept based theory. Organization Science, 4, 577-594.

[11] Araujo, Elidio De, Budiman Christiananta, Lena Ellitan, Bambang Widjanarko Otok, 2013, Confirmation factor analysis on strategic leadership, corporate culture, good corporate governance and company performance, Social Sciences and Humanities, www.jornals.savap.org.pk 